\title{
Fabrikasi dan Karakterisasi Sensor Elektrokimia untuk Mendeteksi Kadmium Berbasis Teknologi Film Tebal
}

\author{
Riska Sri Wahyuni ${ }^{* 1}$, Robert V. M. ${ }^{2}$, Arifin $^{3}$ \\ ${ }^{1,3}$ Departemen Fisika, Fakultas Matematika dan Ilmu Pengetahuan Alam, \\ Universitas Hasanuddin, Indonesia \\ ${ }^{2}$ Pusat Penelitian Elektronika dan Telekomunikasi Lembaga Ilmu Pengetahuan \\ Indonesia (PPET-LIPI), Indonesia \\ Email: "11 riskaasw@gmail.com
}

\begin{abstract}
Abstrak
Fabrikasi dan karakterisasi elektroda sensor elektrokimia telah dilakukan untuk mendeteksi logam berat kadmium $(C d)$ dengan metode teknologi film tebal. Fabrikasi elektroda sensor elektrokimia dimulai dengan tahap perancangan pola elektroda, pembuatan masking, pencetakan sensor, dan pemotongan substrat. Proses tersebut menghasilkan sensor sebanyak sepuluh buah yang akan digunakan untuk karakterisasi sensor berupa SEM, XRD, dan Siklik Voltametri $(C V)$. Proses karakterisasi menghasilkan morfologi dan sifat struktur dari komposit $N / I L / G$, serta nilai linieritas sebesar 0,9623, presisi berkisar antara 4,11 sampai 10,35\%, sensitivitas sebesar $0,04112 \mu \mathrm{A} \cdot \mathrm{L}^{-1} / \mathrm{mg} \cdot \mathrm{mm}^{2}$, limit deteksi sensor $0,18 \mathrm{mg} / \mathrm{L}$, dan nilai akurasi antara 79,5 sampai $126,8 \%$.
\end{abstract}

Kata kunci-SEM, XRD, Siklik Voltametri

\begin{abstract}
Electrochemical sensor has been fabrication and characterization electrode to detect heavy metals of cadmium with thick film technology. Fabrication electrodes electrochemical sensors start with the design stage of electrodes, screen maker, screen printing, and substrate cutting. The fabrication process produces a ten-pieces of sensors to be used to sensors characterization of SEM, XRD, and Cyclic Voltammetry (CV). The process of characterization produces morphology and the structure of the composites N/IL/G, and linieritas 0,9623, precision ranges between 4,11 and $10,35 \%$, sensitivity of $0,04112 \mu A \cdot L-1 / \mathrm{mg}^{-\mathrm{mm}^{2}}$, limit detection $0,18 \mathrm{mg} / \mathrm{L}$, and accuracy between 79,5 and $126,8 \%$.
\end{abstract}

Keywords-SEM, XRD, Cyclic Voltammetry

\section{PENDAHULUAN}

Pemantauan lingkungan hidup merupakan salah satu masalah yang sangat penting dan paling banyak dibahas saat ini. Kelompok logam berat adalah salah satu yang paling dipantau, karena menghasilkan efek yang jelas merusak lingkungan dan kesehatan manusia serta bioakumulasi melalui rantai makanan [1,2]. Logam berat banyak dijumpai pada air minum, udara, dan particular organisme hidup, baik dalam bentuk elemen maupun kompleks [3]. Sifat 
logam berat yaitu sulit didegrasi, sehingga mudah terakumulasi dalam lingkungan dan keberadaannya secara alami sulit terurai (dihilangkan) [4,5]. Jenis logam berat yang sangat beracun pada lingkungan yaitu kadmium (Cd). Hal ini disebabkan karena kadmium memiliki toksisitas yang ekstrem. Kadmium merupakan bahaya lingkungan yang sangat potensial. Efek serius dari paparan kadmium menjadi keharusan mengembangkan metode yang cepat dan sensitivitas untuk penentuan kadmium [6,7].

Salah satu kemungkinan untuk pengukuran ekologis logam berat adalah penggunaan elektroda padat. Elektroda padat dapat diintegrasikan ke dalam sistem sensor kecil yang dapat dibuat menggunakan proses teknologi film tebal. Keuntungan dari sensor teknologi film tebal adalah dimensi yang dimiliki kecil, kemampuan reproduksi baik, sifat mekanik dan listrik dari elektroda, serta proses fabrikasi dapat diakses dengan baik. Keuntungan yang penting adalah biaya material elektroda yang murah sehingga elektroda digunakan untuk sejumlah analisis, pengoperasian mudah, stabilitas sangat baik, sensitivitas tinggi, batas deteksi rendah, dan memiliki perubahan besar untuk penggunaan material [2,8]. Graphene $(\mathrm{G})$ merupakan material yang memiliki konduktivitas termal dan pembawa muatan yang sangat tinggi, luas permukaan spesifik besar, kekuatan mekanik baik, serta sifat listrik yang luar biasa. Ionic Liquid (IL) mrupakan material yang memiliki konduktivitas ion yang tinggi dan digunakan sebagai pelarut elektrokimia, serta pengubah elektroda pada pembuatan sensor. Nafion $(\mathrm{N})$ merupakan material yang digunakan untuk meningkatkan sensitivitas deteksi terhadap logam berat dan digunakan sebagai pengubah elektroda untuk molekul organik. Komposit N/IL/G dapat digunakan sebagai jenis bahan elektroda yang kuat dan canggih untuk penentuan logam berat [8].

Pada penelitian sebelumnya, telah dilakukan pembuatan sensor elektrokimia dengan sreen printed electrode (SPE) yang dikembangkan sebagai sensor sekali pakai untuk berbagai aplikasi dalam analisis lingkungan, industri, dan klinis. Salah satu variasi dari SPE yaitu screen printed carbon electrode (SPCE) yang telah banyak menarik perhatian karena modifikasi yang mudah dibuat, baik dengan pengubah permukaan elektroda atau penambahan karbon sebelum elektroda terbuat. Metode SPCE diterapkan untuk menentukan seng, kadmium, dan timbal dan dipilih sebagai bahan elektroda karena teknologi screen printing adalah cara yang cepat serta dapat mengurangi biaya untuk membuat elektroda sensor yang kuat dan padat $[8,9]$. Terdapat juga penelitian mengenai metode baru yang digunakan untuk menentukan kadmium dengan square wave anodic stripping voltammetry (SWASV) menggunakan film bismuth yang dimodifikasi dengan multiwalled carbon nanotubes didoping dengan elektroda pasta karbon [10].

Pada penelitian ini, dilakukan fabrikasi sensor menggunakan metode teknologi film tebal untuk menentukan logam berat kadmium dan karakterisasi elektroda sensor. Elektroda sensor yang dibuat memiliki keunggulan pada desain yang serba guna, produksi berbiaya rendah sehingga memungkinkan penggunaan sensor sekali pakai, pengujian sensor yang lebih mudah dan lebih praktis karena dapat dibaca secara langsung oleh komputer. Material yang digunakan diharapkan dapat mempengaruhi sifat sensor elektrokimia sehingga dapat dilakukan uji kadar logam berat kadmium.

IJEIS Vol. 10, No. 2, October 2020 : $121-130$ 


\section{METODE PENELITIAN}

Pada penelitian ini, dilakukan fabrikasi elektroda sensor dimulai dengan proses perancangan pola elektroda sampai dengan pemotongan substrat. Perancangan pola elektroda dilakukan menggunakan software CorelDrawX7 dengan empat layout berukuran $2 \times 2$ inch. Pola elektroda ini meliputi: kaki elektroda, elektroda pembanding (reference), elektroda kerja (working) dan pendukung (counter), serta enkapsulasi seperti ditunjukkan pada Gambar 1. Hasil perancangan pola elektroda ini akan dijadikan acuan untuk pembuatan sensor.

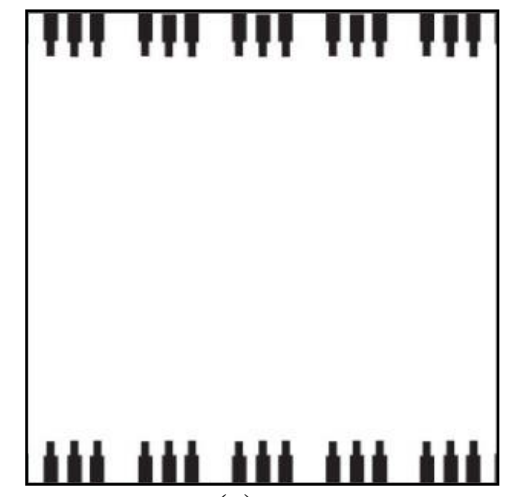

(a)

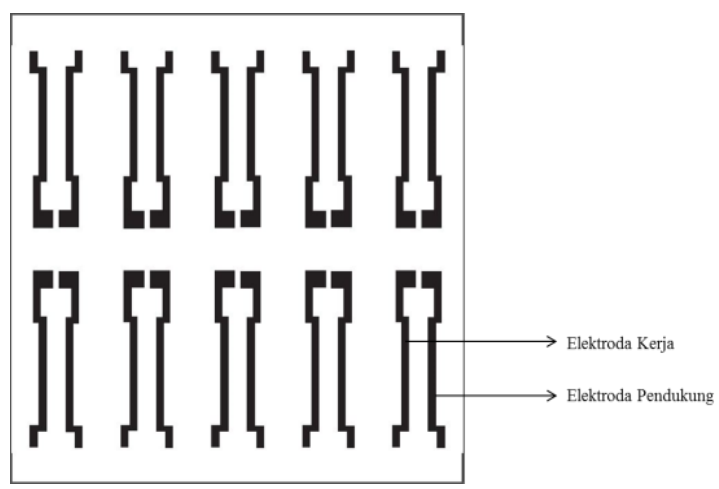

(c)

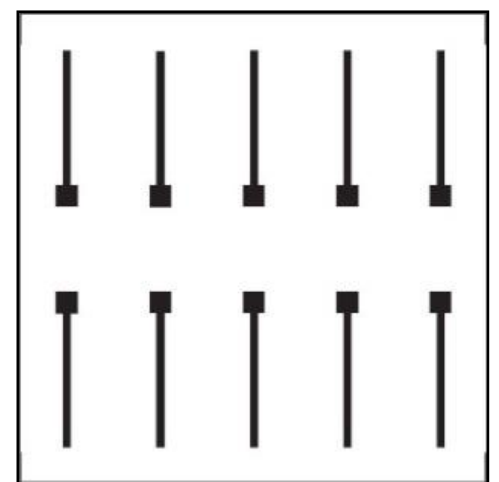

(b)

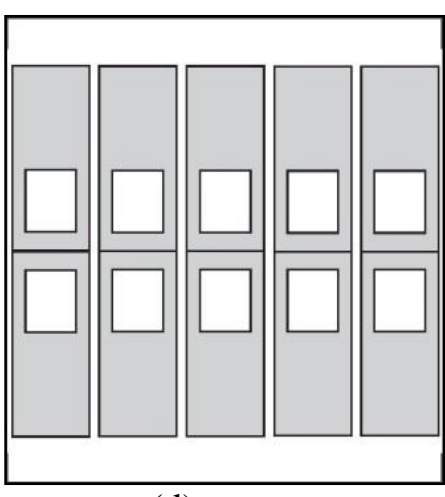

(d)

Gambar 1 Pola elektroda sensor (a) kaki elektroda; (b) elektroda pembanding

(c) elektroda kerja dan pendukung; (d) enkapsulasi

Desain pola elektroda dicetak ke dalam kertas repro film, kemudian dipindahkan ke dalam screen mesh melalui proses screen maker yang dilakukan pada ruang gelap. Proses screen maker menggunakan Screen Maker 300 TT Richmond. Sebelumnya, dibuat terlebih dahulu pasta yang merekatkan screen dan kertas CDF yaitu mencampurkan ulano 133 dan ulano 133 sensitizer secukupnya kemudian diaduk rata hingga teksturnya berubah menjadi pasta (tidak kental atau tidak terlalu encer). Pasta yang sudah dibuat diletakkan pada bagian belakang screen dan diratakan menggunakan rakel sehingga kertas CDF dapat menempel pada screen. Kemudian, dikeringkan menggunakan pengering sehingga tidak ada pasta yang masih basah. Proses selanjutnya yaitu proses screen printing mengikuti tahapan pencetakan teknologi film tebal yang disesuaikan dengan bahan yang digunakan. 
Pencetakan pertama yaitu kaki elektroda dengan bahan perak, dipanaskan pada suhu $300{ }^{\circ} \mathrm{C}$ selama 30 menit. Pencetakan kedua yaitu elektroda pembanding dengan bahan perak, dipanaskan pada suhu $300{ }^{\circ} \mathrm{C}$ selama 20 menit. Kemudian, dilakukan pembakaran dengan suhu tinggi yaitu $750{ }^{\circ} \mathrm{C}$. Pencetakan ketiga yaitu elektroda kerja dan pendukung dengan bahan karbon, dipanaskan pada suhu $170{ }^{\circ} \mathrm{C}$ selama 20 menit. Pencetakan terakhir yaitu enkapsulasi dengan pasta dielektrik, dipanaskan pada suhu $170{ }^{\circ} \mathrm{C}$ selama 20 menit. Proses screen printing ditunjukkan pada Gambar 2.

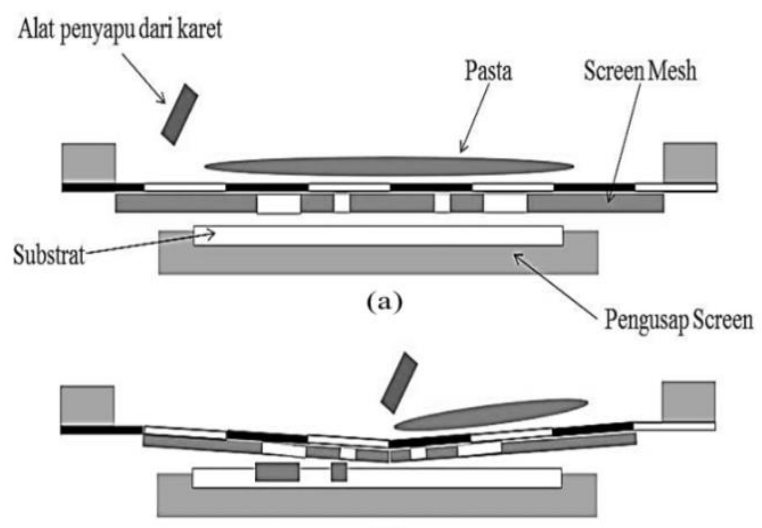

(b)

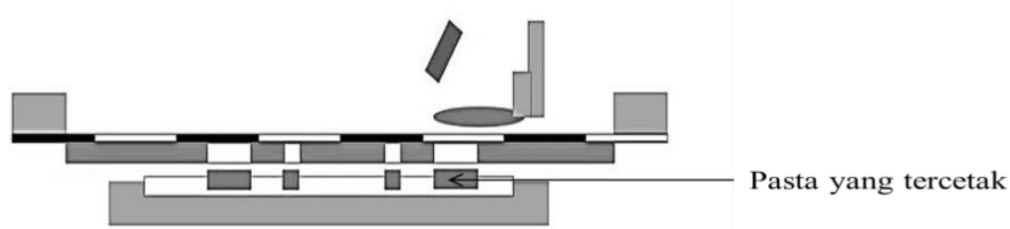

(c)

Gambar 2 Proses screen printing (a) Pemberian pasta; (b) Proses screen;

(c) Pencetakan pasta

Setelah proses pencetakan, dilakukan pemotongan substrat yang menghasilkan sepuluh buah sensor. Proses selanjutnya yaitu modifikasi elektroda pembanding dengan metode electroplating. Metode ini dilakukan dengan penambahan larutan $\mathrm{KCl} 2 \mathrm{M}$ pada elektroda pembanding dengan bantuan energi listrik. Proses ini menghasilkan elektroda pembanding berbahan perak menjadi perak/perak klorida $(\mathrm{Ag} / \mathrm{AgCl})$. Untuk pembuatan komposit N/IL/G, 1 mg graphene dicampurkan dengan $1 \mathrm{~mL}$ DMF menggunakan ultrasonic cleaner selama 2 jam. Selanjutnya, cairan ionik (IL) sebanyak $0,5 \%$ dan nafion $(\mathrm{N})$ sebanyak $0,1 \%$ ditambahkan ke komposit graphene kemudian disonikasi selama 30 menit. Setelah itu, komposit N/IL/G diteteskan pada elektroda kerja sebanyak $1 \mu \mathrm{L}$.

Sampel dibuat dengan $3 \mathrm{~mL}$ larutan kadmium standar $1.000 \mathrm{mg} / \mathrm{L}$ dicampurkan $297 \mathrm{~mL}$ deionized water. Pengukuran elektrokimia dilakukan untuk mengukur nilai arus dan potensial setiap konsentrasi sampel dengan meneteskan sampel sebanyak $50 \mu \mathrm{L}$ pada permukaan sensor yang tidak tertutup enkapsulasi. Skema pengujian sensor dengan siklik voltametri ditunjukkan pada Gambar 3. 


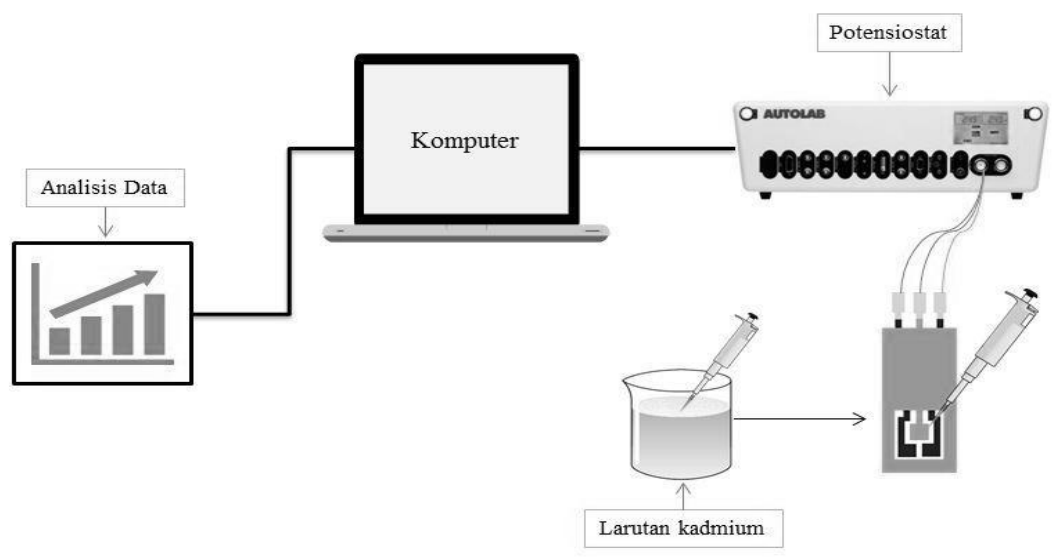

Gambar 3 Skema pengujian sensor

\section{HASIL DAN PEMBAHASAN}

\subsection{Karakterisasi Morfologi Komposit N/IL/G}

Morfologi atau bentuk dan ukuran partikel diketahui melalui karakterisasi SEM. Karakterisasi SEM merupakan karakterisasi yang menggunakan teknik mikroskop elektron dengan cara yang relatif sederhana [11]. Hasil karakterisasi SEM dari permukaan komposit N/IL/G diperlihatkan pada Gambar 4.

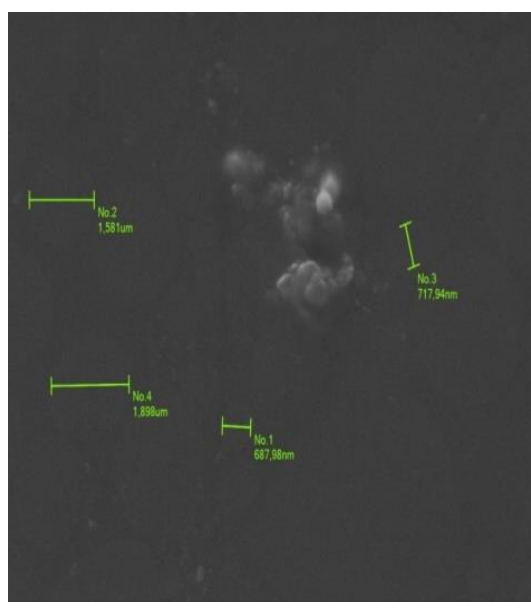

(a)

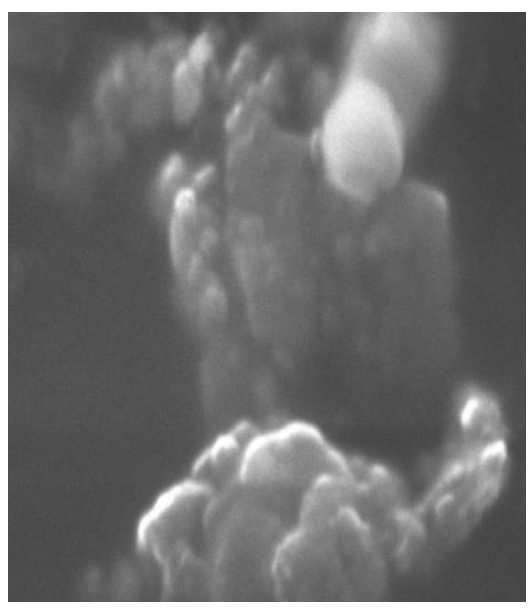

(b)

Gambar 4 Hasil morfologi komposit N/IL/G (a) 10.000 kali; (b) 50.000 kali

Hasil karakterisasi morfologi dari komposit N/IL/G dengan perbesaran 10.000 dan 50.000 kali menghasilkan ukuran partikel $1 \mu \mathrm{m}$ dan $0,5 \mu \mathrm{m}$. Bentuk morfologi lebih jelas pada perbesaran 50.000 kali dengan ukuran partikel yang lebih kecil. Permukaan komposit N/IL/G memiliki morfologi yang berbentuk sebuah padatan yang tidak teratur dan lapisan yang terpisah. Hal ini disebabkan karena cairan ionik dan nafion memiliki konduktivitas yang baik dan viskositas tinggi, sehingga mampu mendispersikan material graphene lebih baik dalam pasta 
sehingga komposit N/IL/G dapat digunakan sebagai bahan elektroda yang kuat untuk penentuan logam berat [8].

\subsection{Karakterisasi Struktur Komposit N/IL/G}

Struktur suatu komposit diketahui melalui karakterisasi XRD. Karakterisasi XRD merupakan karakterisasi yang menggunakan interaksi antara sinar-X dengan atom yang tersusun dalam sebuah sistem struktur kristal [11]. Grafik hubungan antara sudut difraksi terhadap intensitas pada karakterisasi XRD ditunjukkan pada Gambar 4.

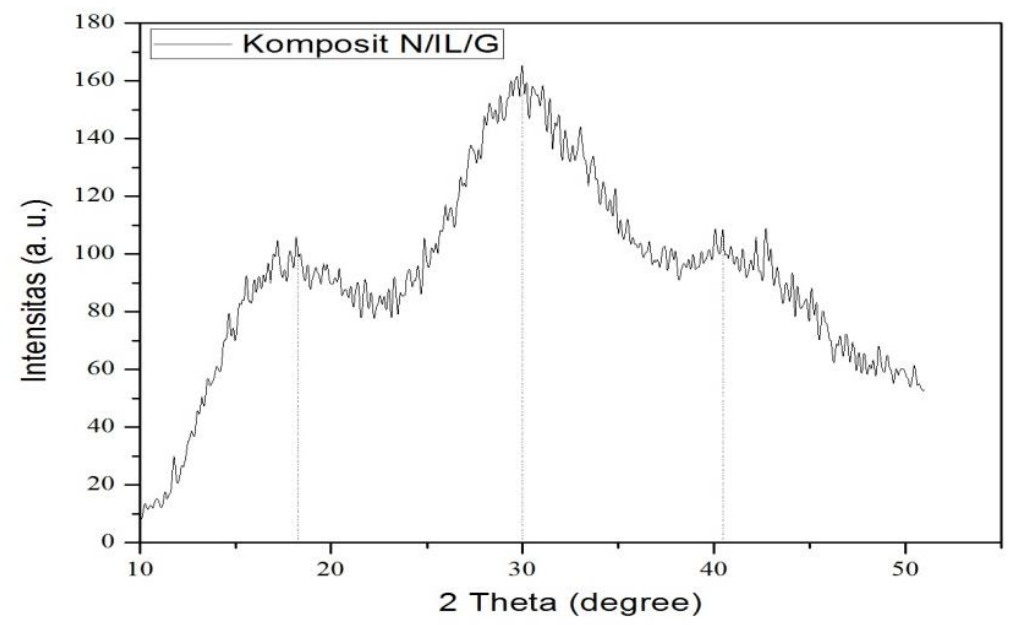

Gambar 4 Grafik hubungan sudut difraksi (20) terhadap intensitas

Pada Gambar 4, terdapat tiga puncak, yaitu sekitar $18,11^{\circ}, 30^{\circ}$, dan $42,12^{\circ}$. Kenaikan puncak pada $2 \theta=30^{\circ}$ membentuk susunan yang hexagonal dan memiliki lapisan atom [12].

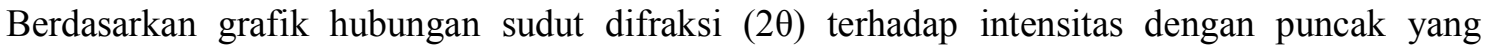
dihasilkan maka, diperoleh sifat struktur dari komposit N/IL/G yaitu bersifat kristal.

\subsection{Karakterisasi Cyclic Voltammetry $(\mathrm{CV})$}

Karakterisasi CV dilakukan untuk mengetahui kevalidasian metode yang digunakan. Siklik voltamogram dari karakterisasi CV yang menunjukkan hubungan tegangan terhadap arus pada setiap konsentrasi dapat dilihat pada Gambar 5.

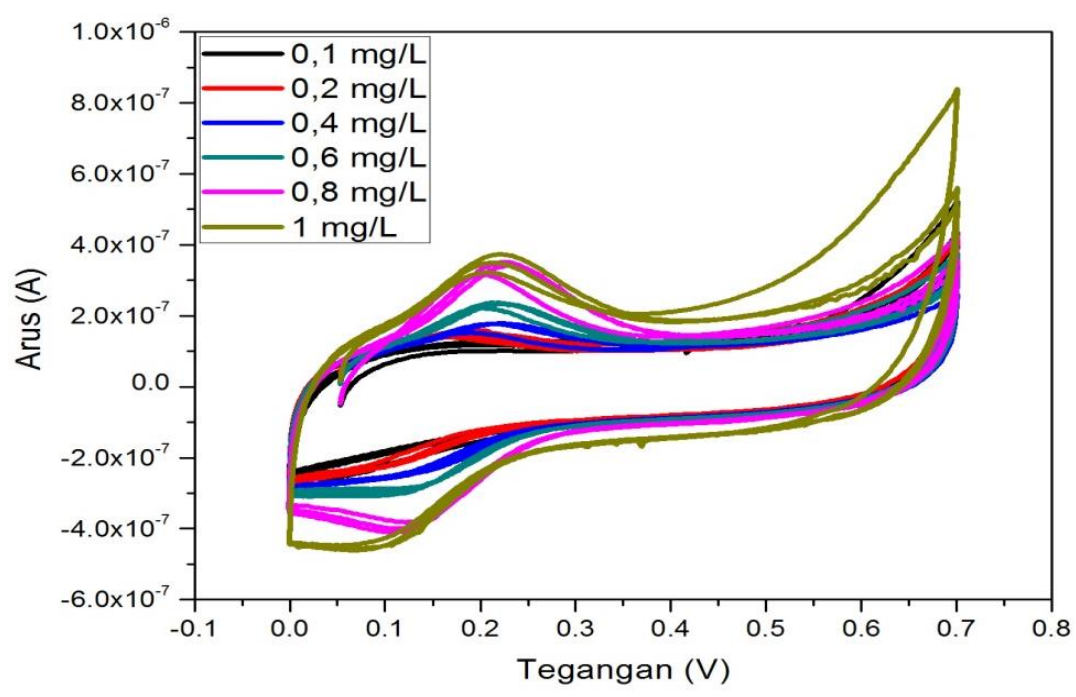

IJEIS Vol. 10, No. 2, October 2020 : $121-130$ 


\subsubsection{Linieritas}

Gambar 5 Siklik voltamogram larutan kadmium

Linieritas sensor diperoleh dari nilai koefisien korelasi (r) kurva standar larutan kadmium atau kurva hubungan konsentrasi sampel terhadap arus yang dihasilkan pada setiap konsentrasi [13]. Data nilai arus ditunjukkan pada Tabel 1 dan kurva diperlihatkan pada Gambar 6.

Tabel 1 Nilai arus pada setiap konsentrasi

\begin{tabular}{|c|c|c|c|c|c|}
\hline \multirow{2}{*}{ No. } & \multirow{2}{*}{$\begin{array}{c}\text { Konsentrasi } \\
(\mathrm{mg} / \mathrm{L})\end{array}$} & 1 & 2 & 3 & \multirow{3}{*}{$\begin{array}{c}\text { Arus } \\
(\mathrm{A})\end{array}$} \\
\cline { 3 - 5 } & 0,1 & $1,03 \times 10^{-7}$ & $1,27 \times 10^{-7}$ & $1,18 \mathrm{E}-07$ & $1,16 \times 10^{-7}$ \\
\hline 1 & 0,2 & $1,57 \times 10^{-7}$ & $1,39 \times 10^{-7}$ & $1,42 \mathrm{E}-07$ & $1,46 \times 10^{-7}$ \\
\hline 2 & 0,4 & $1,52 \times 10^{-7}$ & $1,75 \times 10^{-7}$ & $1,78 \mathrm{E}-07$ & $1,68 \times 10^{-7}$ \\
\hline 3 & 0,6 & $2,17 \times 10^{-7}$ & $2,33 \times 10^{-7}$ & $2,34 \mathrm{E}-07$ & $2,28 \times 10^{-7}$ \\
\hline 4 & 0,8 & $3,10 \times 10^{-7}$ & $3,44 \times 10^{-7}$ & $3,30 \mathrm{E}-07$ & $3,28 \times 10^{-7}$ \\
\hline 5 & 1,0 & $3,22 \times 10^{-7}$ & $3,49 \times 10^{-7}$ & $3,73 \mathrm{E}-07$ & $3,48 \times 10^{-7}$ \\
\hline 6 & & & & & \\
\hline
\end{tabular}

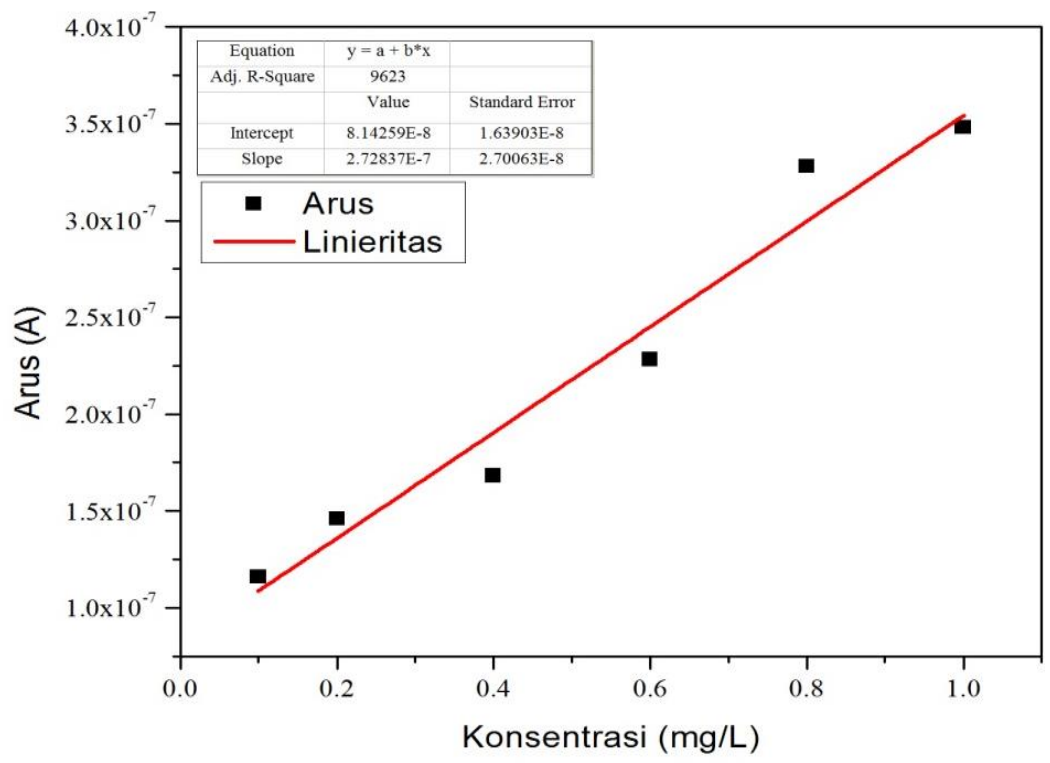

Gambar 6 Kurva hubungan konsentrasi terhadap arus

Pada penelitian ini, diperoleh nilai linieritas sensor sebesar 0,9623 dengan persamaan y $=8,14 \times 10^{-8}+2,73 \times 10^{-7} \mathrm{x}$. Nilai linieritas sensor yang diperoleh tersebut menunjukkan bahwa arus akan semakin meningkat dengan bertambahnya konsentrasi larutan kadmium yang dianalisis.

\subsubsection{Presisi (Ketelitian)}

Presisi diperoleh dari nilai koefisien variasi (\% KV) setiap konsentrasi larutan yang digunakan pada pembuatan kurva hubungan konsentrasi terhadap arus (Gambar 6) [13]. Data 
koefisien variasi pada konsentrasi larutan kadmium dengan tiga siklik dapat dilihat pada Tabel 2.

Tabel 2 Nilai koefisien variasi larutan kadmium

\begin{tabular}{|c|c|c|c|c|c|}
\hline No. & $\begin{array}{c}\text { Konsentrasi } \\
(\mathrm{mg} / \mathrm{L})\end{array}$ & $\begin{array}{c}\text { Arus Rata-Rata } \\
(\mathrm{A})\end{array}$ & $\begin{array}{c}\text { Standar Deviasi } \\
(\mathrm{SD})\end{array}$ & $\begin{array}{c}\text { RSD } \\
(\%)\end{array}$ & $\begin{array}{c}\text { Koefisien Variasi } \\
(\%)\end{array}$ \\
\hline 1 & 0,1 & $11,6 \times 10^{-8}$ & $1,20 \times 10^{-8}$ & 0,1035 & 10,35 \\
\hline 2 & 0,2 & $14,6 \times 10^{-8}$ & $9,41 \times 10^{-9}$ & 0,0645 & 6,45 \\
\hline 3 & 0,4 & $16,8 \times 10^{-8}$ & $1,45 \times 10^{-8}$ & 0,0860 & 8,60 \\
\hline 4 & 0,6 & $22,8 \times 10^{-8}$ & $9,38 \times 10^{-9}$ & 0,0411 & 4,11 \\
\hline 5 & 0,8 & $32,8 \times 10^{-8}$ & $1,74 \times 10^{-8}$ & 0,0531 & 5,31 \\
\hline 6 & 1,0 & $34,8 \times 10^{-8}$ & $2,53 \times 10^{-8}$ & 0,0726 & 7,26 \\
\hline
\end{tabular}

Presisi dinyatakan dengan persentase Relative Standar Deviasion (\% RSD) dengan batas-batas yang masih dapat diterima berdasarkan ketelitiannya. Tingkat ketelitiannya terdiri dari nilai RSD $\leq 1 \%$ berarti sangat teliti, $1 \%<\mathrm{RSD} \leq 2 \%$ berarti teliti, $2 \%<\mathrm{RSD}<5 \%$ berarti ketelitian sedang, RSD $>5 \%$ berarti ketelitian rendah [14].

Dari hasil perhitungan pada Tabel 1, diperoleh nilai RSD $\leq 1 \%$ yang menunjukkan bahwa sensor memiliki ketelitian yang sangat bagus dan nilai koefisien variasi berkisar antara 4,11 sampai $10,35 \%$. Koefisien variasi untuk konsentrasi kecil memiliki nilai yang besar, sedangkan konsentrasi besar memiliki nilai yang relatif lebih rendah. Hal ini menunjukkan bahwa presisi (ketelitian) sensor akan semakin bagus apabila konsentrasi larutan yang dianalisis semakin besar.

\subsubsection{Sensitivitas}

Sensitivitas sensor diperoleh dari nilai slope pada persamaan regresi kurva standar kadmium (Gambar 6) dibagi dengan luas permukaan elektroda sensor. Nilai slope yang diperoleh dari persamaan pada Gambar 6 yaitu $2,73 \times 10^{-7}$ dan luas permukaan sensor sebesar $6,635 \mathrm{~mm}^{2}$. Sehingga, sensitivitas elektroda sensor untuk mendeteksi logam berat kadmium yang diperoleh sebesar $4,112 \times 10^{-8}$ A.L $L^{-1} / \mathrm{mg} . \mathrm{mm}^{2}$. Hal ini menunjukkan bahwa arus akan meningkat sebesar $4,112 \times 10^{-8}$ A pada setiap peningkatan konsentrasi larutan kadmium yang dianalisis.

\subsubsection{Limit Deteksi}

Limit deteksi suatu sampel diperoleh dari perhitungan menggunakan data kurva standar larutan kadmium. Perhitungan tersebut yaitu tiga kali nilai standar error dibagi nilai slope [13]. Nilai standar error sebesar $1,64 \times 10^{-8}$ dan nilai slope sebesar $2,73 \times 10^{-7}$, sehingga pada penelitian ini diperoleh limit deteksi dari larutan kadmium sebesar $0,18 \mathrm{mg} / \mathrm{L}$. Hal ini menunjukkan bahwa konsentrasi terkecil yang dapat dideteksi yaitu konsentrasi $0,18 \mathrm{mg} / \mathrm{L}$.

\subsubsection{Akurasi}

Nilai akurasi diperoleh dari hasil analisis larutan kadmium secara siklik voltametri dengan konsentrasi yang berbeda-beda. Nilai akurasi ini diperoleh dengan membagi konsentrasi 
larutan yang terukur dengan konsentrasi larutan sebenarnya dikali 100\% [12]. Hasil perhitungan nilai akurasi ditunjukkan pada Tabel 3.

Tabel 3 Nilai akurasi larutan kadmium

\begin{tabular}{|c|c|c|c|}
\hline No. & $\begin{array}{c}\text { Konsentrasi Sebenarnya } \\
(\mathrm{mg} / \mathrm{L})\end{array}$ & $\begin{array}{c}\text { Konsentrasi Terukur } \\
(\mathrm{mg} / \mathrm{L})\end{array}$ & $\begin{array}{c}\text { Akurasi } \\
(\%)\end{array}$ \\
\hline 1 & 0,1 & 0,1268 & 126,8 \\
\hline 2 & 0,2 & 0,2365 & 118,2 \\
\hline 3 & 0,4 & 0,3181 & 79,5 \\
\hline 4 & 0,6 & 0,5378 & 89,6 \\
\hline 5 & 0,8 & 0,9035 & 112,9 \\
\hline 6 & 1,0 & 0,9773 & 97,7 \\
\hline
\end{tabular}

Dari hasil perhitungan data akurasi diperoleh rentang akurasi antara 79,5 sampai 126,8\%. Nilai kisaran persentase akurasi yang baik untuk sampel disyaratkan berada pada rentang $100 \% \pm 20 \%$. Rentang tersebut dianggap akurat karena menunjukkan metode tersebut mempunyai ketepatan yang baik dengan tingkat kesesuaian nilai suatu pengukuran yang sebanding dengan nilai sebenarnya [13].

\section{KESIMPULAN}

Karakterisasi morfologi komposit N/IL/G dari analisis SEM menghasilkan bentuk berupa padatan tidak teratur dan lapisan yang terpisah. Analisis XRD menghasilkan sebuah grafik yang menunjukkan bahwa komposit N/IL/G memiliki struktur kristal karena pada puncak intensitas $2 \theta=30^{\circ}$ menunjukkan susunan hexagonal. Analisis sensor dengan siklik voltametri untuk mengukur respon arus terhadap konsentrasi larutan uji menghasilkan nilai linieritas sebesar 0,9623 , presisi berkisar antara 4,11 sampai $10,35 \%$, sensitivitas sebesar $4,112 \times 10^{-8}$ A.L $1 / \mathrm{mg} \cdot \mathrm{mm}^{2}$, limit deteksi sensor $0,18 \mathrm{mg} / \mathrm{L}$, dan nilai akurasi antara 79,5 sampai $126,8 \%$.

\section{SARAN}

Untuk penelitian selanjutnya, sebaiknya dilakukan penyempurnaan desain elektroda sensor dengan pengukuran yang lebih teliti dan menambahkan variasi komposit pada elektroda kerja.

\section{DAFTAR PUSTAKA}

[1] Z. Xu, X. Fan, Q. Ma, B. Tang, Z. Lu, J. Zhang, G. Mo, J. Ye, dan J. Ye. "A Sensitive Electrochemical Sensor for Simultaneous Voltammetric Sensing of Cadmium and Lead based on Fe3O4/Multiwalled Carbon Nanotube/Laser Scribed Graphene Composites Functionalized with Chitosan Modified Electrode", Materials Chemistry and Physics, vol. 584 , no. $19,2019$. 
[2] J. Prasek dan M. Adamek. "Development of New Thick Film Sensor for Heavy Metals Detection", IEEE, pp. 749-752, 2004.

[3] A. Shaha, S. Sultan, A. Zahid, S. Aftab, J. Nisar, S. Nayab, R. Qureshi, G. S. Khan, H. Hussain, S. A. Ozkan. "Highly Sensitive and Selective Electrochemical Sensor for The Trace Level Detection of Mercury and Cadmium", Electrochimica Acta, pp. 1-7, 2017.

[4] Y. Bow. "Penentuan Logam Berat secara Anodic Stripping Voltammetry menggunakan Elektroda Grafit Pensil". Seminar Nasional Forum In Research, Science, and Technology (FIRST), pp. 61-65, 2015.

[5] S. Senthilkumar dan R. Saraswathi. "Electrochemical Sensing of Cadmium and Lead Ions at Zeolite-Modified Electrodes: Optimization and Field Measurements". Sensors and Actuators B: Chemical, vol. 141, pp. 65-75, 2009.

[6] M. M. Radhi, N. K. Al-Damlooji, M. R. Jobayr, dan D. S. Dawood. "Electrochemical Sensors of Cyclic Voltammetry to Detect Cd(II) in Blood Medium". Sensors \& Transducers, vol. 155, no. 8, pp. 150-154, 2013.

[7] Bais R., Sharma P., Rathore P., dan Dubey S.. "Electrochemical Complexation Studies of Cadmium (II) for its Ultra Trace Determination", Research Journal of Chemical Sciences, vol. 3, no. 6, pp. 38-42, 2013.

[8] S. Chaiyo, E. Mehmeti, K. Zagar, W. Siangproh, O. Chailapakul, dan K. Kalcher. "Electrochemical Sensors for The Simultaneous Determination of Zinc, Cadmium and Lead Using a Nafion/Ionic Liquid/Graphene Composite Modified Screen-Printed Carbon Electrode", Analytica Chimica Acta, vol. 2670, no. 16, 2016.

[9] K. T. Rotko, K. Domanska, K. Vytras, R. Metelka, A. N. Wiercinska, dan M. Sys. "Application of Screen-Printed Carbon Electrode Modified with Lead in Stripping Analysis of Cd(II)", Open Chem, vol. 15, no. 10, pp. 28-33, 2017.

[10] J. H. Luo, X. X. Jiao, N. B. Li, dan H. Q. Luo. "Sensitive Determination of Cd(II) by Square Wave Anodic Stripping Voltammetry with in-situ Bismuth-Modified Multiwalled Carbon Nanotubes Doped Carbon Paste Electrodes", Electroanalytical Chemistry 689, pp. 130-134, 2013.

[11] S. Agus, R. Hardian, dan A. Muzakir. Karakterisasi Material: Prinsip dan Aplikasinya dalam Penelitian Kimia. UPI Press, Bandung, 2012.

[12] A. Ngqalakwezi, D. Nkazi, G. Seifert, dan T. Ntho. "Effects of Reduction of Graphene Oxide on The Hydrogen Storage Capacities of Metal Graphene Nanocomposite". Catalysis Today, 2019.

[13] E. N. Hidayati, M. Alauhdin, dan A. T. Prasetya. "Perbandingan Metode Destruksi pada Analisis Pb dalam Rambut dengan AAS". Indo. J. Chem. Sci, vol. 3, no.1, 2014.

[14] A. Kumalasari, A. S. Panggabean, dan E. Akkas. "Pengembangan Metode Rapid Test dalam Penentuan Ash Content dan Calorific Value Batubara di Laboratorium PT Jasa Mutu Mineral Indonesia”. Jurnal Atomik, vol. 2, no. 1, pp. 121-127, 2017. 